\title{
Modeling Soil Carbon from Forest and Pasture Ecosystems of Amazon, Brazil
}

\author{
C. E. P. Cerri,* K. Coleman, D. S. Jenkinson, M. Bernoux, R. Victoria, and C. C. Cerri
}

\begin{abstract}
Conversion of tropical forest to agricultural management has important implications for $\mathrm{C}$ storage in soils and global climate change. The Nova Vida Ranch in the Western Brazilian Amazon basin provided a unique opportunity to study the conversion of tropical forests to pastures established in 1989, 1987, 1983, 1979, 1972, 1951, and 1911, in comparison with uncleared forest. Soils were analyzed for organic $\mathrm{C}$, bulk density, total $\mathrm{N}$, pH, clay content, and biomass $\mathrm{C}$. The forest soil contained $34 \mathrm{Mg} \mathrm{C} \mathrm{ha}^{-1}$ in the 0- to 30 -cm layer: modeling clearance and conversion to pasture caused an initial fall in the $\mathrm{C}$ stock, followed by a slow rise. After $88 \mathrm{yr}$, the pasture soil contained $\mathbf{5 3} \%$ more $\mathbf{C}$ than the forest soil. The increase in total $\mathbf{N}$ on conversion to pasture was less marked, which led to $\mathrm{C} / \mathrm{N}$ ratios in the pasture soils being higher than in the forest soil. The Rothamsted $\mathrm{C}$ turnover model (RothC-26.3) was used to simulate changes in the 0- to 10- and 0- to 30-cm layer of soils when forest was converted to pasture. The model predicted that conversion to pasture would cause a $54 \%$ increase in the stock of organic $C$ in the top $30 \mathrm{~cm}$ of soil in $100 \mathrm{yr}$. The modeled input of plant $\mathrm{C}$ to the 0 - to $30-\mathrm{cm}$ layer of soil under pasture was assumed to be $8.28 \mathrm{Mg} \mathrm{Cha}^{-1} \mathrm{yr}^{-1}$. The model provided a reasonable estimate of the microbial biomass (BIO) $\mathrm{C}$ in the $0-$ to $10-\mathrm{cm}$ soil layer. This was an independent test of model performance, because no adjustments were made to the model to generate output.
\end{abstract}

TAND-USe Change in the tropics is of critical importance in the global $\mathrm{C}$ cycle because: (i) soil organic matter turnover is faster in tropical than in temperate ecosystems (Trumbore et al., 1995); (ii) tropical ecosystems contain large amounts of C (Moraes et al., 1995; Fearnside and Barbosa, 1998; Bernoux et al., 1998a; Cerri et al., 1999); and (iii) land-use change is occurring rapidly in tropical regions (Skole and Tucker, 1993; Neill et al., 1997; Instituto Nacional de Pesquisas Espaciais [INPE], 1998).

Over the last $25 \mathrm{yr}$ more than 70 million ha of native vegetation in Brazil have been replaced by pastures for beef production. The substitution of native vegetation on such a large scale with African grasses (often from the genus Brachiaria) is likely to have an impact on nutrients and organic matter composition, as well as a regional impact on hydrology and water quality. It would be expected to affect $\mathrm{CO}_{2}$ respiration and $\mathrm{C}$ sequestration in soils. In turn, these effects on $\mathrm{C}$ dynamics at large landscape scales would be important in global $\mathrm{C}$ budget and climate change.

C.E.P. Cerri, R. Victoria, and C.C. Cerri, Centro de Energia Nuclear na Agricultura, Universidade de São Paulo, CP.96. Piracicaba, Brazil; K. Coleman and D.S. Jenkinson, Agriculture and the Environment Division, IACR-Rothamsted, Harpenden, Hertfordshire AL5 2JQ, UK; M. Bernoux, Institut de Recherche pour le Développement, France. C.E.P. Cerri is a post-doctoral of the GEF-SOC project (project no. GFL/2740-02-4381). Received 15 Mar. 2003. *Corresponding author (cepcerri@cena.usp.br).

Published in Soil Sci. Soc. Am. J. 67:1879-1887 (2003).

(c) Soil Science Society of America

677 S. Segoe Rd., Madison, WI 53711 USA
One striking example of such changes is the replacement of forest by pasture in the Amazon Basin (Moraes et al., 1996; Piccolo et al., 1996; Steudler et al., 1996; Fearnside and Barbosa, 1998; Cerri et al., 1999). The Amazon Basin covers an area of some 7 million $\mathrm{km}^{2}$, and the central part is almost entirely located within Brazilian territory (Pires and Prance, 1986). This region has the highest rates of deforestation in the world (Skole and Tucker, 1993; INPE, 1998). Between 15000 and $29000 \mathrm{~km}^{2}$ of forest were cleared every year over the past two decades, and the total area deforested now exceeds $500000 \mathrm{~km}^{2}$ (INPE, 1998). Cattle pasture dominates this once-forested land in most of the basin (Pires and Prance, 1986; Skole and Tucker, 1993). Fearnside and Barbosa (1998) estimated that $75 \%$ of the deforested land had been managed as pasture at one stage or another.

A decline in soil C stocks is almost universally observed when tropical forest is cleared and cropped (Batjes and Sombroek, 1997; Shang and Tiessen, 1997; Lal, 1998; Bruce et al., 1999). In contrast, pasture grasses have the potential to introduce large amounts of organic matter to the soil (Fisher et al., 1994; Boddey et al., 1996; Rezende et al., 1999). Increased soil C concentrations in surface horizons are a common consequence of pasture formation from cleared moist tropical forest in the Amazon Basin (Bonde et al., 1992; Moraes, 1995; Trumbore et al., 1995; Moraes et al., 1996; Neill et al., 1997; Bernoux et al., 1998a). Fearnside and Barbosa (1998) reviewed soil $\mathrm{C}$ changes brought about by conversion of the Brazilian Amazon forest to pasture and found that pasture soils can be a net sink or a net source of C, depending on management.

Our goal in this paper was to model long-term impacts of converting forest to pasture on $\mathrm{C}$ stocks, using data collected from the Nova Vida ranch in the Western Brazilian Amazon basin. Some of these data are new and some come from earlier work.

\section{MATERIALS AND METHODS}

\section{Description of the Study Area}

The study area is located in the Western Brazilian Amazon Basin, in the state of Rondônia, at the Nova Vida Ranch $\left(62^{\circ}\right.$ $49^{\prime} 27^{\prime \prime} \mathrm{W}$ long.; $10^{\circ} 10^{\prime} 05^{\prime \prime} \mathrm{S}$ lat.), between the cities of Ariquemes and Jaru. The climate of the region is humid tropical, with a dry season from May to September. Annual rainfall is $2200 \mathrm{~mm}$. Annual mean temperature is $25.6^{\circ} \mathrm{C}$. Mean temperature for the warmest and coolest months varies by $<5^{\circ} \mathrm{C}$ and mean annual relative humidity is $89 \%$ (Bastos and Diniz, 1982).

Abbreviations: BIO, microbial biomass; CEC, effective cation exchange capacity; DPM, decomposable plant material; HUM, humified organic matter; INPE, Instituto Nacional de Pesquisas Espaciais; IOM, inert organic matter; RothC, the Rothamsted C turnover model; RPM, resistant plant material; RMSE, root mean square error; M, mean difference between measurements and simulation. 
The Nova Vida Ranch covers an area of 22000 ha, and is a mixture of native forest and pastures of different ages. Different areas of the ranch were converted from forest to pasture in 1989, 1987, 1983, 1979, 1972, 1951, and 1911. Dates of conversion were established from Nova Vida records and from satellite images (Moraes et al., 1996). All the pastures studied in this work are within $5 \mathrm{~km}$ of each other and the study area has a similar topography (Moraes et al., 1996; Steudler et al., 1996).

According to Neill et al. (1997) this chronosequence represents one of the longest sequences in the Amazon region. The pastures were converted directly from forest without intermediate use for annual crops. This makes them particularly valuable for evaluating the effects of continuous pasture, without the confounding factor of those brief cropping phases that are common in the Amazon and which complicate many pastures studies.

Soils are classified as Podzólicos Vermelho-Amarelo (Red Yellow Podzolic) in the Brazilian classification scheme and as Ultisols (kandiuldults) in the U.S. soil taxonomy (Moraes et al., 1995). This soil type covers about $35 \%$ of the Brazilian Amazon Basin (Bernoux et al., 1998a; Bernoux et al. 1998b; Cerri et al., 1999). According to Moraes et al. (1996), the Red Yellow Podzolic occurs on both the top and the upper slope of the low hills that characterize this region. Below the leaf litter, the surface horizon is normally a very thin $(10 \mathrm{~cm})$ layer of bleached sand. The A horizon is a weakly structured sand clay loam, about $10 \mathrm{~cm}$ thick. The $\mathrm{AB}$ horizon extends to $25 \mathrm{~cm}$. The B1 horizon is brown or yellowish red, gradually changing with depth to a sandy clay, with a weakly developed blocky structure. The underlying B2 horizon is yellowish red to red, soft, porous, sandy clay in texture with a massive structure. The lower part of this horizon may contain up to $50 \%$ gravel and stones (from $2-20 \mathrm{~cm}$ in diameter) composed of flat ferruginous sandstone, subrounded ferruginous rock, and angular and subangular quartz. The average depth of this gravel and stone layer is $150 \mathrm{~cm}$, with an observed range of 50 to $250 \mathrm{~cm}$. In the underlying BC layer, no gravel is encountered but some fragments of weathered rock can be observed. The clay minerals consist of kaolinite and small amounts of gibbsite in both $\mathrm{B}$ and $\mathrm{C}$ horizons.

The native forest vegetation of the ranch is classified as "open humid tropical forest," with large numbers of palms. The most common palms are Orbignya barbosiana, Oenocarpus spp., Jessenia bataua, Euterpe precatoria, and Maximiliana regia (Pires and Prance, 1986). Selective logging removed three or four economically valuable trees per hectare in the forest sites between 1987 and 1990 (Piccolo et al., 1996). The pasture sites were developed by a slash and burn technique used to clear the original forest and then establish the grass species (Graça et al., 1999). This was done by cutting brush in March, followed by tree harvest in June and July. The remaining trees and bush were burned at the beginning of the next rainy season in September or early October, followed by seeding of pasture grasses. All pastures were created in a similar manner. The pastures cleared in 1989, 1987, 1972, and 1911 are dominated by brachiarão (Brachiaria brizantha) and the pastures cleared in 1983, 1979, and 1951 are dominated by colonião (Panicum maximum). Mechanized agricultural practices or chemical fertilizers were not used on any of the pastures (Steudler et al., 1996).

\section{Soil Chemical, Physical, and Biological Properties}

Most of the soil data used in this paper was taken from Feigl et al. (1995), Moraes (1995), Moraes et al. (1996), Neill et al. (1996), Piccolo et al. (1996), and Fernandes et al. (2001)
Table 1. Nova Vida Ranch chronosequence data compiled from different authors (all citations reported forest data).

\begin{tabular}{|c|c|c|}
\hline Citation & Year sampled & $\begin{array}{c}\text { Chronosequence site sampled } \\
\text { (Age in years as of 1999) }\end{array}$ \\
\hline This publication $\dagger+$ & 1999 & $12,16,27,88$ \\
\hline Feigl et al. (1995) $† \S$ & 1991/1992 & $3,5,9,10,12,16,20,42,82$ \\
\hline 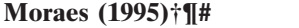 & 1991 & $3,5,9,10,12,16,20,41,88$ \\
\hline Moraes et al. (1996) $\uparrow+\emptyset \#$ & 1992 & $2,3,4,6,9,13,19,27,41,81$ \\
\hline Neill et al. (1996) $\dagger+1+\dagger$ & 1993 & $2,3,5,9,13,20,41,81$ \\
\hline Piccolo et al. (1996) $†$ II & 1994 & $3,5,20$ \\
\hline Fernandes et al. (2001) $\dagger \S$ & 1994 & $3,6,10,12,21,81$ \\
\hline
\end{tabular}

$\dagger$ Total $\mathbf{C}$ and $\mathbf{N}$ content.

$\ddagger$ pH in water.

$\S$ Microbial biomass $\mathbf{C}$ content.

II Bulk density.

\# Clay content.

$\dagger+$ Effective cation-exchange capacity and base saturation.

(Table 1). Soil data from the 1999 sampling has not been previously published (Table 2). Data was combined from pasture sites sampled in 1991, 1992, 1993, 1994, and 1999, which provided a pasture chronosequence of 0 (forest), 2, 3, 4, 5, 6, $9,10,12,13,14,16,19,20,21,27,41,42,81,82$, or $88 \mathrm{yr}$.

In 1999, soil samples were collected from the forest and from pastures created in 1911, 1972, 1983, and 1987. Nine small pits, each spaced $50 \mathrm{~m}$ apart on a 3 by 3 grid, were located on representative areas of the forest and at each pasture site, making a total of 45 soil pits. Soil samples (each $\sim 2 \mathrm{~kg}$ ) were taken by knife from the 0- to 5-, 5- to 10-, 10- to 20-, and 20to $30-\mathrm{cm}$ layers down the side of each pit. Samples were airdried and sieved $(2 \mathrm{~mm})$ to remove stones and root fragments before analysis.

Soil chemical and physical properties for the samples collected in 1999 were analyzed in the same laboratory, using the same techniques that were used to analyze the samples collected in 1991, 1992, 1993, and 1994. This procedure was adopted so that the analytical techniques were consistent over the whole time span, using the same quality controls. Soil bulk density, clay content, $\mathrm{pH}$, effective cation-exchange capacity (CEC), base saturation, soil BIO C, $\mathrm{C}$ and $\mathrm{N}$ concentrations were measured as described by Anderson and Ingram (1989), Embrapa (1979), Piccolo et al. (1996), Moraes et al. (1996), Feigl et al. (1995), and Fernandes et al. (2001).

Bulk density was measured in the field with volumetric steel rings. Particle-size fractions were determined by hydrometer after destruction of organic matter with $\mathrm{H}_{2} \mathrm{O}_{2}$, followed by dispersion in a mixer with sodium hexametaphosphate $(2 \mathrm{~g}$ in $250 \mathrm{~mL}$ water). Soil $\mathrm{pH}$ was measured in water (2.5:1) on air-dried soil. Total $\mathrm{C}$ and $\mathrm{N}$ were measured by dry combustion on a LECO CN elemental analyzer (furnace at $1350^{\circ} \mathrm{C}$ in pure oxygen). Microbial biomass C, measured by Feigl et al. (1995) and Fernandes et al. (2001), was determined using the chloroform fumigation-extraction technique (Brookes et al., 1985; Vance et al., 1987). Soil samples (corresponding to $25 \mathrm{~g}$ of dry weight) were fumigated with $\mathrm{CHCl}_{3}$ for $24 \mathrm{~h}$ at $25^{\circ} \mathrm{C}$ (Jenkinson and Powlson, 1976). After removal of the $\mathrm{CHCl}_{3}$, the $\mathrm{C}$ was extracted from fumigated and unfumigated samples with $0.5 \mathrm{M} \mathrm{K}_{2} \mathrm{SO}_{4}$ for $1 \mathrm{~h}$ on an end-over-end shaker (soil/ solution 1:4). Organic $\mathrm{C}$ in the filtered extracts was determined by the acid dichromate oxidation method. Microbial biomass $\mathrm{C}$ flush (difference between extractable $\mathrm{C}$ from fumigated and unfumigated samples) was converted to soil BIO C using a $K_{\text {EC }}$ factor of 0.30 (Feigl et al., 1995).

\section{Soil Carbon Stocks Adjusted for Bulk Density}

Measurement of soil bulk density is essential to calculate soil C stocks (Bernoux et al., 1998b). Several studies have reported increases in soil bulk density in tropical pastures 
Table 2. Carbon and $N$ concentrations in soil sampled in 1999 under forest and pasture from the Nova Vida Ranch, Brazil.

\begin{tabular}{|c|c|c|c|}
\hline $\begin{array}{l}\text { Land use/pasture } \\
\text { establishment year }\end{array}$ & Pasture age & $\mathbf{C}$ & $\mathbf{N}$ \\
\hline \multirow{2}{*}{\multicolumn{2}{|c|}{$\begin{array}{l}\text { yr } \\
0-5 \mathrm{~cm}\end{array}$}} & \multirow{2}{*}{\multicolumn{2}{|c|}{$\longrightarrow \mathrm{g} \mathrm{kg}^{-1}$}} \\
\hline & & & \\
\hline Forest & & $14.4(5.6) \div$ & $1.2(0.4)$ \\
\hline $1987 \dagger$ & 12 & $28.0(6.4)$ & $1.8(0.4)$ \\
\hline 1983 & 16 & $19.1(3.4)$ & $1.4(0.2)$ \\
\hline 1972 & 27 & 23.4 (3.7) & $1.7(0.3)$ \\
\hline 1911 & 88 & 22.5 (4.1) & $1.8(0.4)$ \\
\hline \multicolumn{4}{|c|}{$\underline{5-10 \mathrm{~cm}}$} \\
\hline Forest & & $9.7(2.0)$ & $0.9(0.2)$ \\
\hline 1987 & 12 & 13.5 (1.7) & $1.2(0.1)$ \\
\hline 1983 & 16 & 11.8 (1.7) & $1.1(0.1)$ \\
\hline 1972 & 27 & 13.0 (1.8) & $1.1(0.1)$ \\
\hline 1911 & 88 & $15.2(2.2)$ & $1.4(0.2)$ \\
\hline \multicolumn{4}{|c|}{$10-20 \mathrm{~cm}$} \\
\hline Forest & & 7.6 (1.5) & $0.7(0.1)$ \\
\hline 1987 & 12 & 9.0 (1.6) & $0.8(0.1)$ \\
\hline 1983 & 16 & 8.7 (1.0) & $0.8(0.1)$ \\
\hline 1972 & 27 & 8.0 (1.5) & 0.7 (0.1) \\
\hline 1911 & 88 & $11.6(1.4)$ & $1.0(0.1)$ \\
\hline \multicolumn{4}{|c|}{$20-30 \mathrm{~cm}$} \\
\hline Forest & & $5.7(0.7)$ & $0.6(0.0)$ \\
\hline 1987 & 12 & $6.2(1.2)$ & $0.6(0.1)$ \\
\hline 1983 & 16 & 6.4 (1.1) & $0.6(0.1)$ \\
\hline 1972 & 27 & $5.8(0.8)$ & $0.6(0.1)$ \\
\hline 1911 & 88 & $7.6(1.2)$ & $0.7(0.1)$ \\
\hline
\end{tabular}

$\dagger$ year of pasture establishment.

$\$$ Numbers in parentheses are standard errors.

relative to the original forest (Bonde et al., 1992; Trumbore et al., 1995; Moraes et al., 1996; Neill et al., 1997; Bernoux et al., 1998b; Fearnside and Barbosa, 1998). We used the methodology described in Moraes et al. (1996), to correct soil $\mathrm{C}$ stocks to an equivalent depth basis, that is, the depth of pasture soil that contains the same mass of soil as the corresponding layer of the original forest. Therefore, we corrected soil C stocks to $30 \mathrm{~cm}$ based on sampling of a soil mass in the pastures that was equal to the mass to $30-\mathrm{cm}$ depth in the native forest. This resulted in calculating $\mathrm{C}$ stocks based on a depth of slightly $<30 \mathrm{~cm}$ when bulk density increased under pasture and slightly $>30 \mathrm{~cm}$ when the bulk density decreased.

\section{The Rothamsted Carbon Model}

We used the Rothamsted Carbon Model (RothC-26.3) to simulate changes in soil $\mathrm{C}$ in the chronosequence. The RothC26.3 (described in detail by Jenkinson et al., 1992; Coleman and Jenkinson, 1996 and Coleman et al., 1997) model predicts organic $\mathrm{C}$ turnover in non-waterlogged topsoils according to soil type, temperature, moisture content, and plant cover. It uses a monthly time step to calculate total $\mathrm{C}, \mathrm{BIO} \mathrm{C}$, and $\Delta^{14} \mathrm{C}$ on a years-to-centuries timescale. In this model, soil organic $\mathrm{C}$ is split into four active fractions and one small inert organic matter (IOM) fraction. The four active fractions are decomposable plant material (DPM), resistant plant material (RPM), $\mathrm{BIO}$, and humified organic matter (HUM). Each fraction decomposes by a first-order process with its own characteristic rate. The IOM fraction is resistant to decomposition.

RothC is solely concerned with soil processes and does not contain a submodel for plant production as does the CENTURY model (Parton et al., 1987). The RothC model's main advantage is that it runs on data that are readily available (Smith et al., 1997).

We used the RothC under the assumptions that (i) all sites were the same before forest clearance and, (ii) that subsequent pasture developments proceeded similarly in the different sites. It is now not possible to check these assumptions because the soils were not sampled when pastures were created, nor was plant productivity measured. However, there were differences in clay content among sites that would not have changed. On the other hand pasture management was similar for all pastures (e.g., establishment, animal stocking rate, grass species), which means disturbance and $\mathrm{C}$ inputs were likely similar across the chronosequences.

\section{Statistical Analysis}

We used the following tests to compare the difference between measured and simulated data from the Nova Vida Ranch chronosequence: sample correlation coefficient $(r)$, root mean square error (RMSE), and mean difference between measurements and simulation (M). Details of these tests can be found in Smith et al. (1996) and Smith et al. (1997).

\section{RESULTS AND DISCUSSION Total Soil and Microbial Biomass Carbon}

The spatial arrangement of the pastures and forests on the study site evolved over time. Thus, this did not provide a robust design for rigorous statistical analysis. None-the-less, the unique chronosequence and use of univariate statistics provides important inferences on $\mathrm{C}$ dynamics and is a basis for predicting long-term effects of pasture on $\mathrm{C}$ stocks in soils. The concentrations of $\mathrm{C}$ and $\mathrm{N}$ in the soils sampled in 1999 are given in Table 2. Table 3 presents a compilation of data from all the work on the Nova Vida soils, including that in Table 2. Where necessary, data for Table 3 were estimated by interpolation, using weighted averages, calculated from data collected in other sampling years in the same pasture. As expected, the lowest $\mathrm{C}$ concentrations in the chronosequence occurred in the forest and in the youngest pasture and the highest concentrations in the oldest pastures (Table 3).

Nitrogen content did not increase with age of the pasture, contrary to $\mathrm{C}$, which did increase. Forest sites showed similar concentrations of $\mathrm{N}$ as pasture areas. In Para, Brazil (which has a similar ecosystem to ours), Buschbacher et al. (1988) also found no clear relationship between soil $\mathrm{N}$ content and pasture age, but that soil $\mathrm{N}$ content was lower in an intensively managed 8 yr-old pasture than a less intensively managed pasture. After pasture establishment, the $\mathrm{N}$ content of the 0 - to 5-cm layer ranged from 1.3 to $1.7 \mathrm{~g} \mathrm{~kg}^{-1}$. In the 5- to $10-\mathrm{cm}$ layer, $\mathrm{N}$ varied from 0.7 to $1.2 \mathrm{~g} \mathrm{~kg}^{-1}$ (Table 3).

Carbon/ $\mathrm{N}$ ratios were generally higher in the surface soils of the pastures than in the native forest (Table 3 ). This behavior is consistent with the relatively greater accumulation of $\mathrm{C}$ compared with $\mathrm{N}$ in the older pastures (Moraes, 1995; Neill et al., 1996).

Forest clearance caused soil $\mathrm{pH}$ in the top $10 \mathrm{~cm}$ to increase by about two units within 5 yr after which it slowly decreased (Table 3 ). Clay content increased with soil depth and was different between sites, but these are not related to pasture age (Moraes et al., 1996; Bernoux et al., 1998a). The bulk density of forest soil in the surface 0 - to $5-\mathrm{cm}$ soil layer ranged from 1.14 to $1.24 \mathrm{Mg} \mathrm{m}^{-3}$ compared with pasture which was higher 
Table 3. Soil properties at depth increments to $30 \mathrm{~cm}$ under forest or pastures established since 1911 to 1989 at Nova Vida Ranch, Brazil.

\begin{tabular}{|c|c|c|c|c|c|}
\hline Land Use & Clay & $\mathbf{C}$ & $\mathbf{N}$ & Bulk density & pH $\left(\mathrm{H}_{2} \mathrm{O}\right)$ \\
\hline & 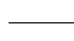 & $\mathrm{g} \mathrm{kg}^{-1}$ & - & $\mathrm{Mg} \mathrm{m}^{-3}$ & \\
\hline & & & & & \\
\hline Forest & 183 & $15.00(4.7) \ddagger$ & $1.3(0.3)$ & $1.19(0.05)$ & $5.1(0.5)$ \\
\hline $1989 \dagger$ & 185 & $15.60(6.3)$ & $1.4(0.5)$ & $1.32(0.11) \S$ & 6.8 (1.1) \\
\hline 1987 & 259 & 22.20 (12.2) & 1.7 (1.1) & $1.32(0.14)$ & $7.6(0.5)$ \\
\hline 1983 & 196 & $19.70(6.4)$ & $1.3(0.4)$ & $1.48(0.09) \S$ & $6.1(0.2)$ \\
\hline 1979 & 203 & 20.10 (10.1) & $1.5(0.5)$ & $1.36(0.11)$ & $6.1(0.1)$ \\
\hline 1972 & 223 & $21.40(5.8) \S$ & $1.5(0.6) \S$ & $1.25(0.10)$ & $5.7(0.4) \S$ \\
\hline 1951 & 248 & $20.20(5.4) \S$ & $1.3(0.4) \S$ & $1.32(0.10)$ & $5.9(0.3) \S$ \\
\hline 1911 & 131 & $23.80(3.2)$ & $1.6(0.7)$ & $1.28(0.05) \S$ & $5.9(0.4)$ \\
\hline & & & & & \\
\hline Forest & 264 & $9.80(1.7)$ & $0.9(0.2)$ & $1.37(0.08)$ & $4.7(0.2)$ \\
\hline 1989 & 289 & 8.50 (1.9) & 0.8 (0.2) & $1.40(0.08) \S$ & $6.4(1.0)$ \\
\hline 1987 & 316 & $11.40(2.7)$ & $1.0(0.8)$ & $1.41(0.08)$ & $7.2(0.3)$ \\
\hline 1983 & 288 & 11.30 (1.9) & 0.9 (0.1) & $1.52(0.10) \S$ & $6.1(0.3)$ \\
\hline 1979 & 242 & $9.80(2.0)$ & 0.7 (0.1) & $1.41(0.05)$ & $6.1(0.3)$ \\
\hline 1972 & 237 & $13.30(3.3) \S$ & $1.1(3.0) \S$ & $1.39(0.08)$ & $5.7(0.3) \S$ \\
\hline 1951 & 251 & $16.20(4.1) \S$ & $1.1(1.8) \S$ & $1.40(0.13)$ & $5.9(0.4) \S$ \\
\hline 1911 & 160 & $16.00(2.4)$ & $1.2(0.9)$ & $1.39(0.07) \S$ & $5.9(0.5)$ \\
\hline & & & & & \\
\hline Forest & 300 & 7.10 (1.2) & $0.6(0.2)$ & $1.44(0.10)$ & $4.5(0.2)$ \\
\hline 1989 & 339 & 7.30 (1.1) & 0.7 (0.1) & $1.46(0.11) \S$ & $5.8(0.9)$ \\
\hline 1987 & 346 & $8.30(2.8)$ & 0.7 (0.3) & 1.39 (0.15) & $6.9(0.3)$ \\
\hline 1983 & 316 & 7.00 (1.1) & $0.6(0.1)$ & $1.51(0.08) \S$ & $6.3(0.3)$ \\
\hline 1979 & 281 & 6.10 (1.4) & $0.5(0.1)$ & $1.43(0.05)$ & $6.2(0.3)$ \\
\hline 1972 & 285 & 7.00 (1.1)§ & $0.7(0.2) \S$ & $1.36(0.07)$ & $5.7(0.3) \S$ \\
\hline 1951 & 292 & $9.10(1.5) \S$ & $0.6(0.2) \S$ & 1.44 (0.11) & $5.8(0.2) \S$ \\
\hline 1911 & 149 & $10.50(1.0)$ & 0.8 (0.1) & $1.47(0.06) \S$ & $5.9(0.5)$ \\
\hline & & & & & \\
\hline Forest & 345 & $5.90(1.1)$ & $0.4(0.2)$ & $1.45(0.05)$ & $4.8(0.3)$ \\
\hline 1989 & 382 & $5.60(1.4)$ & $0.5(0.1)$ & $1.44(0.09) \S$ & $5.5(0.7)$ \\
\hline 1987 & 383 & $6.40(2.5)$ & $0.5(0.1)$ & $1.38(0.11)$ & $6.6(0.7)$ \\
\hline 1983 & 369 & $5.40(1.7)$ & $0.4(0.2)$ & $1.45(0.04) \S$ & $6.4(0.3)$ \\
\hline 1979 & 305 & $4.80(0.8)$ & $0.3(0.1)$ & $1.41(0.07)$ & $6.2(0.4)$ \\
\hline 1972 & 352 & $5.40(0.6) \S$ & $0.5(0.2) \S$ & $1.48(0.08)$ & $5.5(0.4) \S$ \\
\hline 1951 & 345 & $6.80(2.2) \S$ & $0.5(0.1) \S$ & $1.47(0.13)$ & $5.7(0.6) \S$ \\
\hline 1911 & 165 & $7.10(0.3)$ & $0.5(0.3)$ & $1.49(0.05) \S$ & $5.9(0.2)$ \\
\hline
\end{tabular}

$\dagger$ Year of pasture management.

+ Numbers in parentheses are standard errors.

$\S$ Value estimated by interpolation.

and ranged from 1.25 to $1.48 \mathrm{Mg} \mathrm{m}^{-3}$ in the $0-$ to $5-\mathrm{cm}$ layer. Averaging the data in Tables 2, showed that $56 \%$ of the total soil $\mathrm{C}$ was in the top $10 \mathrm{~cm}$.

Carbon stocks in the top $10 \mathrm{~cm}$ tended to increase with pasture age (Table 4). All seven pastures created at different times had higher $\mathrm{C}$ stocks than the forest. The smallest gains were in the youngest pasture and the highest gain, about $11 \mathrm{Mg} \mathrm{ha}^{-1}$, in the oldest.

The $\mathrm{BIO} \mathrm{C}$ in the 0 - to $10-\mathrm{cm}$ layer ranged from 0.29 to $0.86 \mathrm{Mg} \mathrm{C} \mathrm{ha}{ }^{-1}$, the smallest value being observed for the 3-yr-old pasture (Table 4). The forest site contained $0.39 \mathrm{Mg}$ biomass $\mathrm{C} \mathrm{ha}^{-1}$, which represents $2.5 \%$ of the total soil $\mathrm{C}$ in the $0-$ to $10-\mathrm{cm}$ layer. Pasture sites contained between 1.7 to $3.3 \%$ of their total soil $\mathrm{C}$ in microbial C. This range is similar to that reported for tropical soils by Grisi et al. (1998).

The CEC varied from 3.79 to $8.41 \mathrm{cmol}(+) \mathrm{kg}^{-1}$ (Table 4). The CEC increased in young pastures ( 3 and $5 \mathrm{yr}$ old), but thereafter declined to levels markedly below that of the native forest soil. Base saturation increased in young pastures and decreased somewhat in the older pastures, driven by declines in exchangeable base cations and increases in exchangeable $\mathrm{Al}^{3+}$. According to Neill et al. (1997), the short-term increases in soil $\mathrm{pH}$ and in CEC at Nova Vida arise because the forest was cleared by burning.

\section{Modeling the Soil Carbon Dynamics}

\section{Modeling Soil Organic Carbon Before Forest Clearing}

Before fitting the model to the data from the seven pasture sites in the chronosequence, it was necessary to run RothC to generate the $\mathrm{C}$ content in the soil at the starting point, taken to be $34.4 \mathrm{Mg} \mathrm{C}^{-1}$ for all seven preclearing forest sites. At that time the organic $\mathrm{C}$ content of the forest soil was assumed to be in steady state.

To do this, RothC was run for $10000 \mathrm{yr}$ with a DPM/ RPM ratio value of 0.25 , the value specified by Jenkinson et al. (1992) for deciduous or tropical woodland. Inert organic matter was calculated from the equation of Falloon et al. (1998), since the radiocarbon age of the soil had not been measured on any of the soils in Table 3. From the measured C content of the $0-$ to $30-\mathrm{cm}$ layer (34.4 $\mathrm{Mg} \mathrm{C} \mathrm{ha}^{-1}$ ), the Falloon et al. (1998) equation gave a value of $2.75 \mathrm{Mg} \mathrm{C} \mathrm{ha}^{-1}$ as IOM. In the $0-$ to 10-cm layer the measured $\mathrm{C}$ was $15.7 \mathrm{Mg} \mathrm{C}$ ha $^{-1}$ (Table 4), giving an IOM of $1.13 \mathrm{Mg} \mathrm{C} \mathrm{ha}^{-1}$. Although we have no radiocarbon measurements to set IOM, work by Gomes (1995) and Pessenda et al. (1998) indicates that the Falloon et al. (1998) equation is not seriously in error when applied to these samples. From the radiocarbon measurements made by Gomes (1995) on soil sampled in 1994 from a forested area of the Nova 
Table 4. Soil characteristics for a chronosequence of native forest and pastures ranging from 2 to 88 yr at Nova Vida Ranch, Brazil.

\begin{tabular}{|c|c|c|c|c|c|}
\hline \multirow[b]{2}{*}{ Land use } & \multicolumn{2}{|c|}{ C stocks } & \multirow{2}{*}{$\begin{array}{c}\text { Biomass C } \\
0-10 \mathrm{~cm}\end{array}$} & \multirow{2}{*}{$\begin{array}{c}\text { CEC } \dagger \\
\mathbf{0 - 1 0} \mathrm{cm}\end{array}$} & \multirow{2}{*}{$\begin{array}{c}\text { Base saturation } \\
0-10 \mathrm{~cm}\end{array}$} \\
\hline & $0-30 \mathrm{~cm}$ & $0-10 \mathrm{~cm}$ & & & \\
\hline & \multicolumn{2}{|c|}{$\longrightarrow \mathrm{Mg} \mathrm{ha}^{-1}$} & $\mathbf{M g ~ C ~ h a - 1 ~}$ & $\operatorname{cmol}(+) \mathbf{k g}^{-1}$ & $\%$ \\
\hline Forest & $34.4(2.02) \ddagger$ & $15.7(0.92)$ & $0.39(<0.01)$ & 6.09 & 45 \\
\hline Pasture age (yr) & & & & & \\
\hline 2 & $27.8(1.40)$ & $14.3(0.72)$ & - & - & - \\
\hline 3 & 35.3 (1.36) & $17.1(0.66)$ & $0.29(<0.01)$ & 6.90 & 93 \\
\hline 4 & 34.0 (1.07) & $16.3(2.09)$ & - & - & - \\
\hline 5 & 44.6 (4.36) & $24.2(2.61)$ & $0.41(0.02)$ & 8.41 & 96 \\
\hline 6 & 43.9 (4.81) & $23.1(0.66)$ & 0.40 & - & - \\
\hline 9 & $41.2(2.25)$ & 24.3 (1.19) & 0.52 & 5.32 & 91 \\
\hline 10 & 39.3 (2.02) & 21.9 (1.58) & $0.70(0.22)$ & - & - \\
\hline 12 & 49.4 (3.57) & $28.1(2.02)$ & $0.32(0.17)$ & - & - \\
\hline 13 & 36.4 (1.56) & $21.2(0.91)$ & - & 3.79 & 86 \\
\hline 14 & 35.4 (1.85) & 19.9 (1.60) & - & - & - \\
\hline 16 & 43.9 (4.48) & 23.2 (1.98) & $0.86(<0.01)$ & - & - \\
\hline 19 & 29.8 (3.22) & $14.5(2.14)$ & - & - & - \\
\hline 20 & $39.8(2.53)$ & $22.3(0.88)$ & $0.67(0.06)$ & 4.57 & 58 \\
\hline 21 & 38.6 (1.98) & $20.3(1.60)$ & 0.58 & - & - \\
\hline 27 & 43.9 (4.06) & $24.3(2.29)$ & - & - & - \\
\hline 41 & $48.6(2.95)$ & $26.4(0.98)$ & $0.82(0.07)$ & 4.75 & 73 \\
\hline 42 & 46.3 (3.62) & 23.1 (1.42) & $0.71(0.19)$ & - & - \\
\hline 81 & 41.1 (1.77) & $28.3(2.31)$ & $0.66(0.06)$ & 4.74 & 82 \\
\hline 82 & $50.0(1.32)$ & $26.8(0.98)$ & 0.58 & - & - \\
\hline 88 & $52.6(3.12)$ & 24.9 (2.03) & - & - & - \\
\hline
\end{tabular}

$\dagger$ Effective cation-exchange capacity.

$\uparrow$ Numbers in parentheses are standard errors.

Vida ranch, we used RothC to calculate that $6.6 \%$ of the organic $\mathrm{C}$ in the 0 - to $30-\mathrm{cm}$ layer was in IOM. The corresponding value calculated from the Falloon et al. (1998) equation was about $8 \%$. The weather inputs were taken from the meteorological station at Nova Vida Ranch. Except when otherwise noted, the clay content of the soil was taken as the mean (weighted averages) of all the data, that is, $234 \mathrm{~g} \mathrm{~kg}^{-1}$ for the 0 - to $10-\mathrm{cm}$ layer and 286 for the 0 - to $30-\mathrm{cm}$ layer.

The annual input of $\mathrm{C}$ (from plant debris, roots, etc.) needed to generate $34.4 \mathrm{Mg} \mathrm{C} \mathrm{ha}{ }^{-1}$ at the starting point was calculated to be $4.52 \mathrm{Mg} \mathrm{C} \mathrm{ha}^{-1} \mathrm{yr}^{-1}$ for the 0 - to $30-\mathrm{cm}$ layer (monthly input $0.38 \mathrm{Mg} \mathrm{C} \mathrm{ha}^{-1}$ ). In the same manner, to obtain $15.7 \mathrm{Mg} \mathrm{C} \mathrm{ha}^{-1}$ in the 0 - to 10-cm layer we needed an input of $2.04 \mathrm{Mg} \mathrm{C} \mathrm{ha}^{-1} \mathrm{yr}^{-1}$ $\left(0.17 \mathrm{Mg} \mathrm{C} \mathrm{ha}^{-1} \mathrm{mo}^{-1}\right)$.

\section{Predicting Soil Organic Carbon After Forest Clearing}

According to Boddey et al. (1996), pasture needs some time to become fully established after forest clearance. To allow for this, we arbitrarily set the plant input to zero in the first year of pasture creation: thereafter annual input was taken as constant, even though it probably took 2 or 3 yr to achieve this constant value. The input was applied uniformly throughout the year, even though measurements of aboveground production in Brachiaria pastures in Brazil and Colombia show production to be markedly greater in the wet season than in the dry (Boddey et al., 1996; Rezende et al., 1999). Jenkinson et al. (1992) specified two DPM/RPM ratios for grassland: 0.67 for unimproved grassland and scrub; and 1.44 for improved grassland. We decided that the pasture sites at Nova Vida are more similar to improved than unimproved grassland and used a 1.44 DPM/RPM ratio. The 0 - to 30 - and 0 - to $10-\mathrm{cm}$ layers were modeled separately: the weather inputs were used for the forest phase. The clay content used for modeling was $286 \mathrm{~g}$ $\mathrm{kg}^{-1}$ soil in the 0 - to $30-\mathrm{cm}$ layer and $234 \mathrm{~g} \mathrm{~kg}^{-1}$ soil for the $0-$ to $10-\mathrm{cm}$ layer, which was the same for forest.

The annual input was iteratively adjusted to give the least squares best fit between model and data. The best fit for the 0- to 30-cm layer is shown in Fig. 1 for an input of $8.28 \mathrm{Mg} \mathrm{C} \mathrm{ha}^{-1} \mathrm{yr}^{-1}$. Figure 2 shows the corresponding best fit for the 0 - to $10-\mathrm{cm}$ layer; the input is 4.68 $\mathrm{MgC} \mathrm{ha}{ }^{-1} \mathrm{yr}^{-1}$. Visual evaluation shows tolerable agreement between modeled and measured data, especially in older pastures. The model predicts an initial decline in soil $\mathrm{C}$ stock in the first years, following conversion

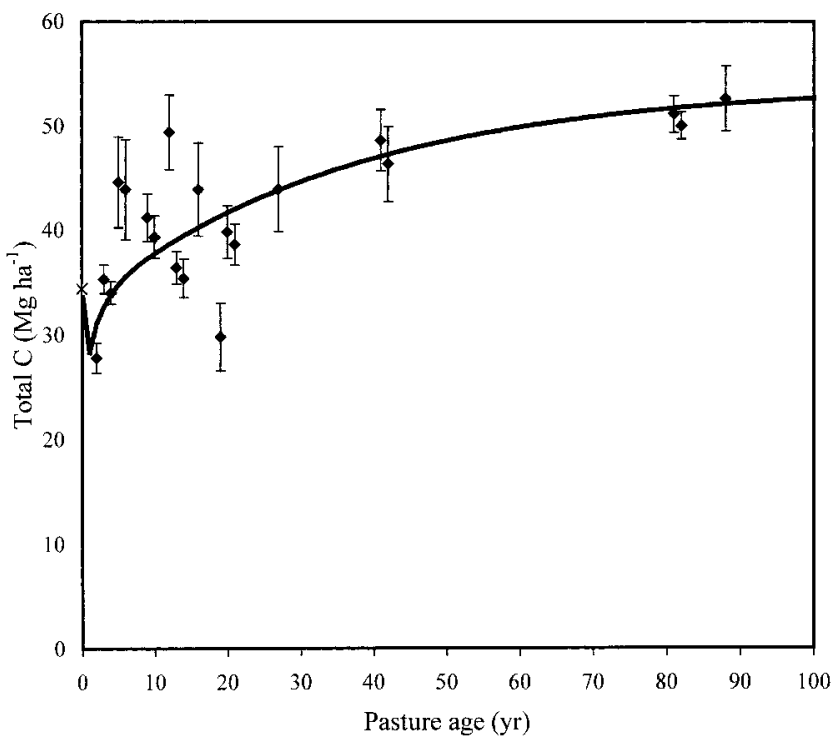

Fig. 1. Predicted (solid line) and measured (symbols) total soil $\mathbf{C}$ in the 0 - to $30-\mathrm{cm}$ layer from the Nova Vida Ranch chronosequence, Brazil. Clay content assumed to be $286 \mathrm{~g} \mathrm{~kg}^{-1}$ and $\mathrm{C}$ input assumed to be $8.28 \mathrm{Mg} \mathrm{ha}^{-1} \mathrm{yr}^{-1}$; pasture age $(\diamond)$ and forest $(*)$. Bars indicate standard errors. 


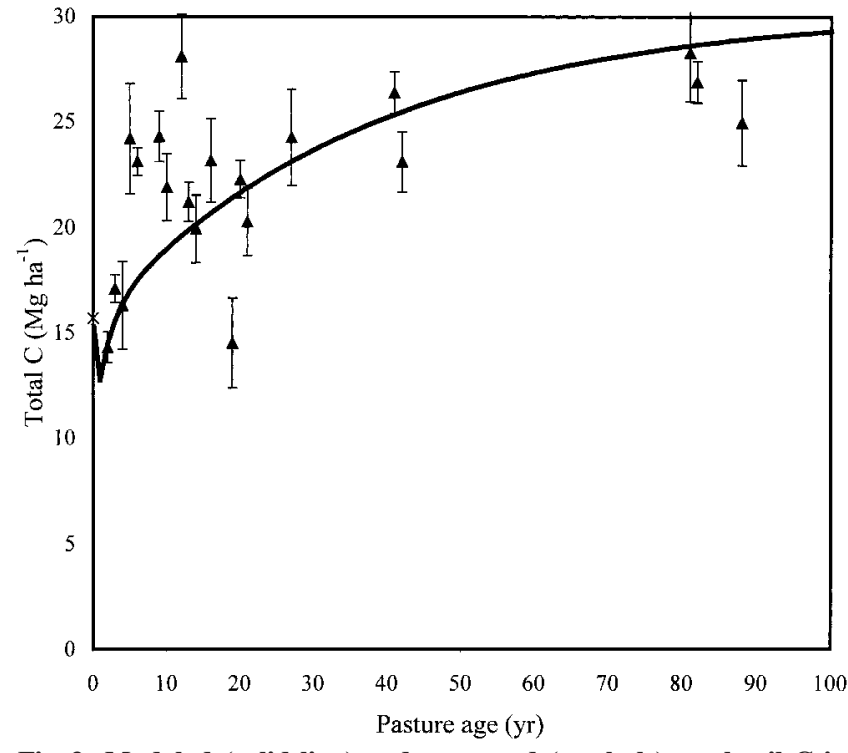

Fig. 2. Modeled (solid line) and measured (symbols) total soil $\mathbf{C}$ in the 0- to 10-cm layer from the Nova Vida Ranch chronosequence, Brazil. Clay content assumed to be $234 \mathrm{~g} \mathrm{~kg}^{-1}$ for all pastures and $\mathrm{C}$ input assumed to be $4.68 \mathrm{Mg} \mathrm{ha}^{-1} \mathrm{yr}^{-1}$; pasture age $(\triangle)$ and forest $(*)$.

from forest to pasture, and then a steady increase during pasture establishment. The qualitative visual examination of the simulations (Fig. 1 and 2) is supported by the statistical analysis. Statistical tests between modeled and measured data in Fig. 1 gave a correlation coefficient $(r)$ of 0.73 , RMSE (showing total error) of $4.93 \%$ and a $\mathrm{M}$ (showing bias) of $0.67 \mathrm{Mg} \mathrm{C} \mathrm{ha}^{-1}$. The corresponding values for Fig. 2 were $0.64,3.69 \mathrm{~m}$, and 0.98 , respectively (Table 5).

The statistical tests given in Table 5 evaluate the model simulations of soil $\mathrm{C}$ content against the measured data to assess the performance of the model. The correlation coefficients of 0.73 and 0.64 show a positive correlation between simulated and measured values. The calculated values of 0.67 and $0.98 \mathrm{Mg} \mathrm{C}^{-1}$ for $\mathrm{M}$ indicate that bias (or consistent error) was small. Because $\mathrm{M}$ does not include a square term, simulated values above and below the measurements cancel out and so any inconsistent errors are ignored (Smith et al., 1996). The coincidence between measured and simulated values were assessed by calculating an absolute value for total difference, expressed as the RMSE. The values found for RMSE (Table 5) indicate that the dif- ferences between measured and simulated values were small. Root mean square error can also be used directly to compare errors in simulations made by different models, a lower value of RMSE indicating a more accurate simulation (Smith et al., 1996). The RMSE values in Table 5 are comparable with those found by Falloon and Smith (2002), who also used RothC to simulate data from six long-term experiments under temperate conditions.

There are no measurements where total annual C input was reduced to compare with our modeled value of $8.28 \mathrm{Mg} \mathrm{C} \mathrm{ha}^{-1} \mathrm{yr}^{-1}$ for the 0- to 30-cm layer of soil, although there are some measurements of aboveground production that are broadly compatible with our calculations. Boddey et al. (1996) measured a mean herbage production (aboveground) of $22.1 \mathrm{Mg} \mathrm{DM} \mathrm{ha}^{-1} \mathrm{yr}^{-1}$ in a range of Brachiaria pastures-equivalent to $8.84 \mathrm{Mg}$ $\mathrm{C} \mathrm{ha}^{-1} \mathrm{yr}^{-1}$. Rezende et al. (1999) developed a value of 20.6 Mg DM ha ${ }^{-1} \mathrm{yr}^{-1}\left(8.24 \mathrm{Mg} \mathrm{C} \mathrm{ha}^{-1} \mathrm{yr}^{-1}\right)$ for Brachiaria pastures with a stocking rate of 2 animals ha ${ }^{-1}$. Herbivores will consume some of this aboveground production, of which part will be returned in feces, making annual return to the soil lower than aboveground production by an amount dependent on intensity of grazing. Belowground production will contribute directly to the annual input.

The most likely explanation for the variation in the stock of soil $\mathrm{C}$ along the chronosequence (Fig. 1 and 2 ) is variability in the input of $\mathrm{C}$ from the pastures, particularly in the early years. Another possible explanation is that there were pre-existing differences in the total amount of soil $\mathrm{C}$ between sites at the time of clearing (Neill et al., 1997). Again this would be most important in the early years after pasture establishment.

Table 2 suggests that a Panicum dominated pasture (that started in 1983) accumulated less $\mathrm{C}$ in the top $10 \mathrm{~cm}$ of soil than pastures dominated by Brachiaria (those started in 1987, 1972, and 1911). However, the unknown spatial variability of soil properties among pastures mean that these differences must be treated with caution.

\section{Analysis of RothC Assumptions}

Figure 3 shows how three of the assumptions made in modeling the data in Fig. 1 affect the fit. The first assumption is related to the DPM/RPM ratio. The value specified in RothC for improved grassland (1.44) gives

Table 5. Statistical tests for agreement between predicted and measured values for organic $\mathrm{C}$ and microbial biomass $\mathrm{C}$ in soils from the pasture chronosequence at Nova Vida Ranch, Brazil.

\begin{tabular}{|c|c|c|c|c|}
\hline \multirow[b]{2}{*}{ Data modeled as a chronosequence } & \multicolumn{4}{|c|}{ Statistical tests } \\
\hline & $r \dagger$ & RMSE $\%$ & M§ & $n$ ๆ \\
\hline & & $\%$ & $\operatorname{Mg~ha}^{-1}$ & \\
\hline Total $\mathrm{C}$ in the 0 to $30-\mathrm{cm}$ soil layer & 0.73 & 4.93 & 0.67 & 21 \\
\hline Total $C$ in the 0 to $10-\mathrm{cm}$ soil layer & 0.64 & 3.69 & 0.98 & 21 \\
\hline Microbial Biomass $\mathrm{C}$ in the 0 to $10-\mathrm{cm}$ soil layer & 0.56 & 0.15 & $\mathbf{0 . 0 3}$ & 14 \\
\hline Perfect fit & 1.00 & 0.00 & 0.00 & \\
\hline
\end{tabular}

$\dagger$ Simple correlation coefficient.

+ Root mean square error.

$\S$ Mean difference between observations and simulation.

Il Number of observations. 


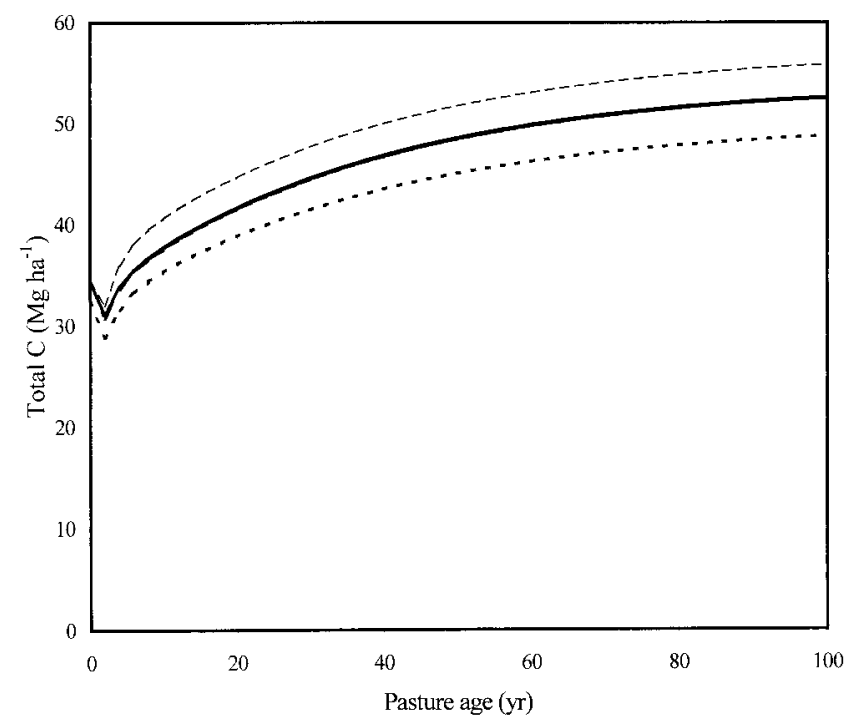

Fig. 3. Effects of varying the DPM/RPM ratio, input distribution and clay content on model outputs. - - - Input $8.28 \mathrm{Mg} \mathrm{C} \mathrm{ha}^{-1} \mathrm{yr}^{-1}$, distributed uniformly through the year; DPM/RPM ratio 1.44; clay content $286 \mathrm{~g} \mathrm{~kg}^{-1}$ soil (same as Fig.1). - - - - Input 8.28 Mg C $\mathrm{ha}^{-1} \mathrm{yr}^{-1}$, distributed uniformly through the year; DPM/RPM ratio 0.67; clay content $286 \mathrm{~g} \mathrm{~kg}^{-1}$ soil. -........- Input $8.28 \mathrm{Mg} \mathrm{C} \mathrm{ha}^{-1}$ $\mathrm{yr}^{-1}$, all added as a simple pulse in June; DPM/RPM ratio 1.44; clay content $286 \mathrm{~g} \mathrm{~kg}^{-1}$ soil. - - - - - Input $8.28 \mathrm{Mg} \mathrm{C} \mathrm{ha}^{-1} \mathrm{yr}^{-1}$, distributed uniformly through the year; DPM/RPM ratio 1.44; clay content $153 \mathrm{~g} \mathrm{~kg}^{-1}$ soil.

the fit shown in Fig. 1 with an input of $8.28 \mathrm{Mg} \mathrm{C} \mathrm{ha}^{-1}$ $\mathrm{yr}^{-1}$. Using a DPM/RPM ratio of 0.67 (as specified for unimproved grassland and scrub) and the same annual input, increases the modeled C content of the soil $100 \mathrm{yr}$ after conversion to pasture by $6.2 \%$ (Fig. 3 ).

The second assumption is the distribution of $\mathrm{C}$ inputs throughout the year. To generate the modeled line in Fig. 1, plant input was distributed evenly through the year. If the entire annual input was added in June and nothing in the other months, the model output is almost indistinguishable from that when the input is evenly distributed (Fig. 3), over the time scales considered in this paper.

The third assumption is the use of average clay content for all the pastures, regardless of the measured content as given in Table 3. Figure 3 illustrates the worst case - the pasture created in 1911, with clay content of $153 \mathrm{~g} \mathrm{~kg}^{-1}$ soil, as opposed to the average for all the soils of $286 \mathrm{~g} \mathrm{~kg} \mathrm{~g}^{-1}$ soil. One hundred years after conversion to pasture the modeled $\mathrm{C}$ content, using $153 \mathrm{~g}$ clay $\mathrm{kg}^{-1}$ soil, of this site is only $7.4 \%$ lower than when modeled with the average clay content (Fig. 3). Smith et al. (2000) examined some of the data in Table 3 and came to a similar conclusion about the effects of clay. It is therefore unlikely that differences in clay content are in themselves sufficient to explain the discrepancies between predicted and measured in Fig. 1 and 2.

\section{Modeling Microbial Biomass Carbon}

Microbial biomass $\mathrm{C}$ measurements provide an independent test of model performance. Fig. 4 shows predicted and measured values for soil $\mathrm{BIO} \mathrm{C}$ in the 0 - to

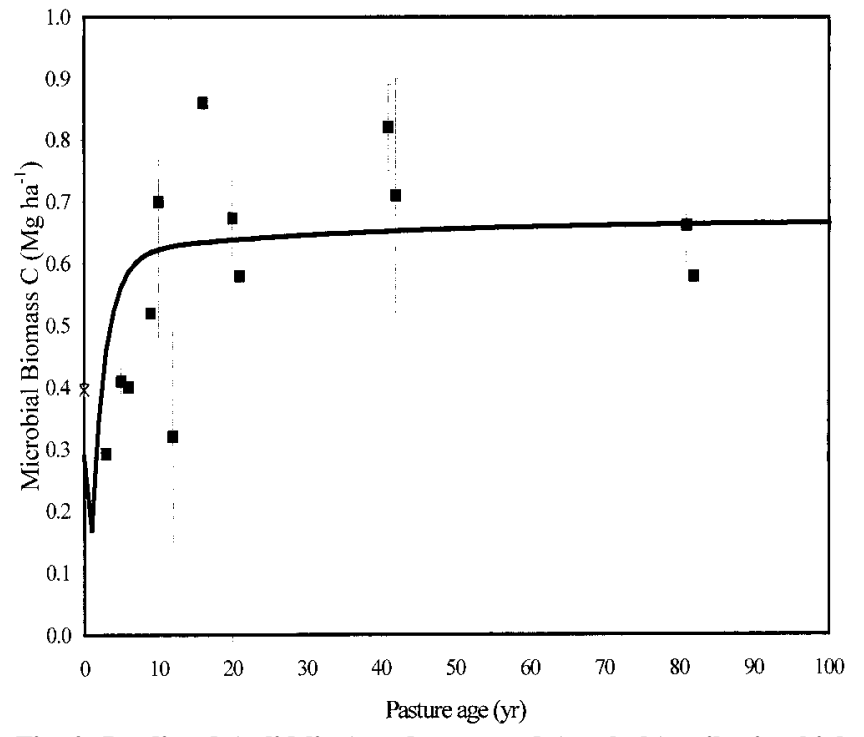

Fig. 4. Predicted (solid line) and measured (symbols) soil microbial biomass $C$ content of the 0 - to $10-\mathrm{cm}$ soil layer from the Nova Vida Ranch chronosequence, Brazil. Clay content assumed to be $234 \mathrm{~g} \mathrm{~kg}^{-1}$ for all pastures and $\mathrm{C}$ input assumed to be $4.68 \mathrm{Mg}$ $\mathrm{ha}^{-1} \mathrm{yr}^{-1}$; pastures created at different times $(\square)$ and forest $(*)$.

10-cm layer of the Nova Vida chronosequence, using the same average clay content $\left(234 \mathrm{~g} \mathrm{~kg}^{-1}\right)$ for all the pastures. The annual input was also set to be the same as in Fig. 2 (4.68 $\mathrm{Mg} \mathrm{C} \mathrm{ha}^{-1} \mathrm{yr}^{-1}$ ). Bearing in mind that no model adjustments were made to generate the values in Fig. 4 and that there were some large errors in measuring $\mathrm{BIO}$; the modeled quantities of soil $\mathrm{BIO} \mathrm{C}$ fit the measured data reasonably well. Table 5 gives the results of statistical tests for the accuracy of the BIO C simulation, and the tests are similar to those already used for total C simulations. The correlation coefficient is less than that for the corresponding total $\mathrm{C}$ simulation, presumably as a result of larger errors in some of the biomass $\mathrm{C}$ measurements. A $\mathrm{M}$ value of $0.03 \mathrm{MgC} \mathrm{ha}{ }^{-1}$ and RMSE value of $0.15 \%$ shows no consistent error in the fitting, and a negligible mean error between simulated and measured data points.

\section{PERSPECTIVES}

The RothC model for the turnover of organic $\mathrm{C}$ gives a plausible representation of the effects of land management on the stocks of $\mathrm{C}$ and of BIO held in the soils of the Nova Vida Ranch. Roth C predicts that conversion to pasture will cause a $54 \%$ increase in the stock of organic $\mathrm{C}$ held in the top $30 \mathrm{~cm}$ of soil in $100 \mathrm{yr}-$ and that this increase will continue after $100 \mathrm{yr}$.

Our conclusions on the turnover of organic C in Amazonian pastures are based on data from a single, wellmanaged ranch. Furthermore, more work is needed on other ranches to determine if the Nova Vida pastures are representative of other pastures in the Amazon region. It is commonly considered that cattle ranching in the Amazon region can never be a profit-making venture, as long as the only revenue is from the sale of cattle. But if monetary incentives or other subsides become available for $\mathrm{C}$ sequestration and land rehabilitation, 
this might provide additional motivation to improve management of areas already converted to pasture.

Models that consider soil, pasture, and animal variables will be essential if we are to understand the impact of management on pasture sustainability and calculate the financial implications of any specified system of management. Models for the turnover of organic $\mathrm{C}$ in soil, such as RothC, can contribute to our understanding of long-term ecosystem sustainability.

\section{ACKNOWLEDGMENTS}

This work was supported by Fundação de Amparo à Pesquisa do Estado de São Paulo (FAPESP-99/07103-0), the Ecosystem Center (Woods Hole/USA), The Global Environment Facility (project no. GFL/2740-02-4381), and IACR-Rothamsted. IACR-Rothamsted was supported with a grant from the UK Biotechnology and Biological Sciences Research Council. We thank Dr. Boris Volkoff for organizing the database, Dr. Brigitte Feigl and Dr. Marisa Piccolo for supplying the soil data and Drs. David Powlson and Pete Smith for discussion on the draft. João Arantes Jr. kindly permitted us to work at Nova Vida Ranch and assisted with logistical support.

\section{REFERENCES}

Anderson, J.M., and J.S.I. Ingram. 1989. Tropical soil biology and fertility: A handbook of methods. CAB International, Wallingford, UK.

Bastos, T.X., and A.S. Diniz. 1982. Avaliação do clima do Estado de Rondônia para desenvolvimento agrícola. Boletim de Pesquisa $\mathrm{n}^{\circ}$ 44. Belém, EMBRAPA-CPATU.

Batjes, N.H., and W.G. Sombroek. 1997. Possibilities for C sequestration in tropical and subtropical soils. Global Change Biology 3: 161-173.

Bernoux, M., D. Arrouays, C.C. Cerri, P.M. de A. Graça, B. Volkoff, and J. Trichet. 1998a. Estimation des stocks de carbone des sols du Rondônia (Amazonie brésilienne). (In French.) Études et gestion des sols, 5:31-42.

Bernoux, M., D. Arrouays, C.C. Cerri, B. Volkoff, and C. Jolivet. 1998b. Bulk density of Brazilian Amazon soils related to other soil properties. Soil Sci. Soc. Am. J. 62:743-749.

Boddey, R.M., I.M. Rao, and R.J. Thomas. 1996. Nutrient cycling and environmental impacts of Brachiaria pastures. p. 72-86. In J.L. Miles et al. Brachiaria: Biology, agronomy and improvement. CIAT, Cali, Colombia

Bonde, T.A., B.T. Christensen, and C.C. Cerri. 1992. Dynamics of soil organic matter as reflected by natural ${ }^{13} \mathrm{C}$ abundance in particle size fractions of forested and cultivated Oxisols. Soil Biol. Biochem. 24:275-277.

Brookes, P.C., J.F. Kragt, D.S. Powlson, and D.S. Jenkinson. 1985. Chloroform fumigation and the release of soil nitrogen: The effects of fumigation time and temperature. Soil Biol. Biochem. 17: 831-835.

Bruce, J.P., M. Frome, E. Haites, H. Janzen, R. Lal, and K. Paustian. 1999. Carbon sequestration in soils. J. Soil Water Conserv. 54: 382-389.

Buschbacher, R., C. Uhl, and A.S. Serrao. 1988. Abandoned pastures in eastern Amazonia. II. Nutrient stocks in the soil and vegetation. J. Ecol. 76:682-699.

Cerri, C.C., M. Bernoux, D. Arrouays, B.J. Feigl, and M.C. Piccolo. 1999. Carbon stocks in soils of the Brazilian Amazon. p. 33-50. In R. Lal et al. (ed.) Global Climate Change and Tropical Ecosystems. Advances in Soil Science, CRC Press, Boca Raton, FL.

Coleman, K., and D.S. Jenkinson. 1996. RothC-26.3-A model for the turnover of carbon in soil. p. 237-246. In D.S. Powlson et al. (ed.) Evaluation of soil organic matter models using existing longterm datasets. NATO ASI Series I, vol. 38. Springer, Berlin.

Coleman, K., D.S. Jenkinson, G.J. Crocker, P.R. Grace, J. Klir, M. Korschens, P.R. Poulton, and D.D. Richter. 1997. Simulating trends in soil organic carbon in long-term experiments using RothC-26.3. Geoderma 81:29-44.

Embrapa. 1979. Manual de método de análise do solo. (In Portuguese.) Empresa Brasileira de Pesquisa Agropecuária/SNLCS. Rio de Janeiro.

Falloon, P., P. Smith, K. Coleman, and S. Marshall. 1998. Estimating the size of the inert organic matter pool for use in the Rothamsted carbon model. Soil Biol. Biochem. 30:1207-1211.

Falloon, P., and P. Smith. 2002. Simulating SOC changes in long-term experiments with RothC and Century: Model evaluation for a regional scale application. Soil Use Manage. 18:101-111.

Feigl, B.J., G.P. Sparling, D.J. Ross, and C.C. Cerri. 1995. Soil microbial biomass in Amazon soils: Evaluation of methods and estimates of pool size. Soil Biol. Biochem. 27:1467-1472.

Fearnside, P.M., and R.I. Barbosa. 1998. Soil carbon changes from conversion of forest to pasture in Brazilian Amazon. For. Ecol. Manage. 108:147-166.

Fernandes, S.A.P., C.C. Cerri, M. Bernoux, B.J. Feigl, and M.C.S. Carvalho. 2001. Carbon and nitrogen of the soil microbial biomass, composition in ${ }^{13} \mathrm{C}$, and fluxes of gases in Amazon (Rondônia). Soil Biol. Biochem. in press.

Fisher, M.J., I.M. Rao, M.A. Ayarza, C.E. Lascano, J.I. Sanz, R.J. Thomas, and R.R. Vera. 1994. Carbon storage by introduced deeprooted grasses in the South American savanas. Nature 371:236-238.

Gomes, B.M. 1995. Estudo Paleoambiental no Estado de Rondônia utilizando datacão ${ }^{14} \mathrm{C}$ e razão ${ }^{13} \mathrm{C} /{ }^{12} \mathrm{C}$ da matéria orgânica do solo [Palaeoenvironmental studies in the state of Rondônia using radiocarbon dating and the $13 \mathrm{C} / 12 \mathrm{C}$ ratio of soil organic matter]. (In Portuguese.) Master Thesis, Universidade de São Paulo, Centro de Energia Nuclear na Agricultura, Piracicaba, SP, Brazil.

Graça, P.M.L.A., P.M. Fearnside, and C.C. Cerri. 1999. Burning of Amazon forest in Ariquemes, Rondônia, Brazil: Biomass, charcoal formation and burning efficiency. For. Ecol. Manage. 120:179-191.

Grisi, B., C. Grace, P.C. Brookes, A. Benedetti, and M.T. Dell'Albate. 1998. Temperature effects on organic matter and microbial biomass dynamics in temperate and tropical soils. Soil Biol. Biochem. 30: 1309-1315.

INPE. 1998. Amazônia: Desflorestamento 1995-1997. (In Portuguese.) São José dos Campos, SP.

Jenkinson, D.S., and D.S. Powlson. 1976. The effects of biocidal treatments on metabolism in soil-V. A method for measuring soil biomass. Soil Biol. Biochem. 8:209-213.

Jenkinson, D.S., D.D. Harkness, E.D. Vance, D.E. Adams, and A.F Harrison. 1992. Calculating net primary production and annual input of organic matter to soil from the amount and radiocarbon content of soil organic matter. Soil Biol. Biochem. 24:295-308.

Lal, R. 1998. Soil processes and the greenhouse effect. p. 199-212. In R. Lal et al.. Methods for assessment of soil degradation. CRC Press, Boca Raton, FL.

Moraes, J.F.L. 1995. Propriedades do solo e dinamica da materia organica associadas as mudancas do uso da terra em Rondonia (RO)/Brazil. (In Portuguese.) Ph.D. thesis, Universidade de São Paulo, Centro de Energia Nuclear na Agricultura, SP, Brazil.

Moraes, J.F.L., C.C. Cerri, J.M. Melillo, D. Kicklighter, C. Neill, D. Skole, and P.A. Steudler. 1995. Soil carbon stocks of the Brazilian Amazon basin. Soil Sci. Soc. Am. J. 59:244-247.

Moraes, J.F.L., B. Volkoff, C.C. Cerri, and M. Bernoux. 1996. Soil properties under Amazon forest change due to pasture installation in Rondônia, Brazil. Geoderma 70:63-81.

Neill, C., B. Fry, J. Melillo, P.A. Steudler, J.F.L. Moraes, and C.C. Cerri. 1996. Forest and pasture derived carbon contributions to carbon stocks and microbial respiration of tropical pasture soils. Oecologia 107:113-119.

Neill, C., C.C. Cerri, J. Melillo, B.J. Feigl, P.A. Steudler, J.F.L. Moraes, and M.C. Piccolo. 1997. Stocks and dynamics of soil carbon following deforestation for pasture in Rondonia. p. 9-28. In R. Lal et al. (ed.) Soil processes and the carbon cycle. CRC Press, Boca Raton, FL.

Parton, W.J., D.S. Schimel, C.V. Cole, and D.S. Ojima. 1987. Analysis of factors controlling soil organic matter levels in Great Plains grasslands. Soil Sci. Soc. Am. J. 51:1173-1179.

Pessenda, L.C.R., B.M. Gomes, R. Aravena, A.S. Ribeiro, R. Boulet, and S.E.M. Gouveia. 1998. The carbon isotope record in soils along a forest-cerrado ecosystem transect: Implications for vegetation 
changes in the Rondonia State, southwestern Brazilian Amazon. Holocene 8:599-603.

Piccolo, M.C., C. Neill, J. Melillo, C.C. Cerri, and P.A. Steudler. 1996. ${ }^{15} \mathrm{~N}$ natural abundance in forest and pasture soils of the Brazilian Amazon Basin. Plant Soil 182:249-258.

Pires, J.M., and G.T. Prance. 1986. The vegetation types of the Brazilian Amazon. p. 109-115. In G.T. Prance and T.M. Lovejoy (ed.) Amazonia. Pergamon Press, Oxford.

Rezende, C.P., R.B. Cantaruti, J.M. Braga, J.A. Gomide, J.M. Pereira, E. Ferreira, R. Tarre, R. Machado, B.J.R. Alves, S. Urquiaga, G. Cadish, K.E. Giller, and R.M. Boddey. 1999. Litter decomposition and disappearance in Brachiaria pastures in the Atlantic forest region of the South of Bahia, Brazil. Nutr. Cycling Agroecosyst. 54:99-112.

Shang, C., and H. Tiessen. 1997. Organic matter lability in a tropical Oxisol: Evidence from shifting cultivation, chemical oxidation, particle size, density, and magnetic fractionations. Soil Sci. 162: 795-807.

Skole, D., and C. Tucker. 1993. Tropical deforestation and habitat fragmentation in the Amazon satellite data from 1978 to 1988. Science 260:1905-1910.

Smith, J.U., P. Smith, and T. Addiscott. 1996. Quantitative methods to evaluate and compare soil organic matter (SOM) models. p. 181-200. In D.S. Powlson et al. (ed.) Evaluation of soil organic matter models using existing, long-term datasets. NATO ASI Series I, Vol. 38, Springer-Verlag, Berlin.

Smith, P., J.U. Smith, D.S. Powlson, W.B. McGill, J.R.M. Arah, O.G. Chertov, K. Coleman, U. Franko, S. Frolking, D.S. Jenkinson, L.S. Jensen, R.H. Kelly, Klein-Gunnewiek, A.S. Komarov, C. Li, J.A.E. Molina, T. Mueller, W.J. Parton, J.H.M Thornley and A.P. Whitmore. 1997. A comparison of the performance of nine soil organic matter models using datasets from seven long-term experiments. Geoderma 81:153-225.

Smith, P., P. Falloon, K. Coleman, J. Smith, M.C. Piccolo, C. Cerri, M. Bernoux, D. Jenkinson, J. Ingram, J. Szabó, and L. Pásztor. 2000. Modeling soil carbon dynamics in tropical ecosystems. p. 341-364. In R. Lal, J. Kimble and B.A. Stewart. (ed.) Global climate change and tropical ecosystems. CRC Press, Boca Raton, FL.

Steudler, P.A., J.M. Melillo, B.J. Feigl, C. Neill, M.C. Piccolo, and C.C. Cerri. 1996. Consequence of forest-to-pasture conversion on $\mathrm{CH}_{4}$ fluxes in the Brazilian Amazon Basin. J. Geophys. Res. 101:18547-18554.

Trumbore, S.E., E.A. Davidson, P.B. de Camargo, D.C. Nepstad, and L.A. Martinelli. 1995. Below-ground cycling of carbon in forest and pastures of Eastern Amazonia. Global Biogeochem. Cycles 9:515-528.

Vance, E.D., P.C. Brookes, and D.S. Jenkinson. 1987. An extraction method for measuring soil microbial biomass C. Soil Biol. Biochem. 19:703-707. 